\title{
The "Stop" and "Go" of Nicotine Dependence: Role of GABA and Glutamate
}

\author{
Manoranjan S. D'Souza and Athina Markou \\ Department of Psychiatry, School of Medicine, University of California San Diego, La Jolla, California 92093 \\ Correspondence: amarkou@ucsd.edu
}

Nicotine plays an important role in the initiation and maintenance of tobacco smoking. Importantly, chronic nicotine exposure alters the function of brain reward systems, resulting in the development of a nicotine-dependent state. This nicotine-dependent state is associated with aversive affective and somatic signs upon abstinence from smoking, often leading to relapse in abstinent smokers. This article reviews the role of the major excitatory and inhibitory neurotransmitters glutamate and $\gamma$-aminobutyric acid (GABA), respectively, in both the reinforcing effects of nicotine and development of nicotine dependence. Evidence suggests that blockade of glutamatergic neurotransmission attenuates both nicotine intake and nicotine seeking. In contrast, both nicotine intake and nicotine seeking are attenuated when GABA neurotransmission is facilitated. In conclusion, medications that either attenuate/ negatively modulate glutamatergic neurotransmission or facilitate/positively modulate GABA neurotransmission may be useful for promoting smoking cessation in humans.

$\mathrm{T}_{\mathrm{r}}^{\mathrm{o}}$ obacco smoking is a chronic compulsive and relapsing disorder that results in significant morbidity and mortality worldwide (Giovino 2007; World Health Organization 2008; Centers for Disease Control and Prevention 2011). Although tobacco smoke contains thousands of chemicals, nicotine is the major psychoactive component that is largely responsible for the maintenance of the harmful tobacco smoking habit in humans (Henningfield and Goldberg 1983; Stolerman and Jarvis 1995). The central actions of nicotine are mediated by nicotinic acetylcholine (nACh) receptors that are distributed throughout the brain (Martin and Aceto 1981; Changeux 2010). The majority of the currently approved medications for smoking cessation focus on manipulating nicotine intake by modulating these nicotinic receptors (Stack 2007; Benowitz 2010). The success rates of these nicotinic receptor-based medications are low, with much scope for improvement (Agboola et al. 2010). To accelerate the discovery and development of new medications for smoking cessation, understanding the neural substrates that mediate the development of nicotine dependence is essential.

The actions of nicotine in the brain are mediated by excitatory nACh receptors. These excitatory $\mathrm{nACh}$ receptors are present on several different types of neurons and regulate the release of a number of neurotransmitters, including the major excitatory and inhibitory neurotransmitters in the brain, namely glutamate and $\gamma$-aminobutyric acid (GABA) (Wonnacott

Editors: R. Christopher Pierce and Paul J. Kenny

Additional Perspectives on Addiction available at www.perspectivesinmedicine.org

Copyright (C) 2013 Cold Spring Harbor Laboratory Press; all rights reserved; doi: 10.1101/cshperspect.a012146

Cite this article as Cold Spring Harb Perspect Med 2013;3:a012146 
1997). The present review focuses on the role of glutamate and GABA in nicotine dependence. More specifically, this review covers the following: (1) the effects of acute nicotine administration on glutamatergic and GABAergic neurotransmission; (2) alterations in glutamatergic and GABAergic neurotransmission after chronic nicotine exposure; and (3) the effects of pharmacological modulation of glutamatergic and GABAergic neurotransmission in animal models that assess different aspects of nicotine dependence. Identifying and targeting nonnicotinic neural substrates, such as those involved in glutamatergic and GABAergic neurotransmission, will help expand the repertoire of smoking cessation treatments and result in more efficacious medications for the treatment of nicotine dependence than those currently available.

\section{NICOTINE DEPENDENCE}

Nicotine dependence can be broadly divided into three phases. In humans, the initial phase of the acquisition and maintenance of nicotine seeking is mediated by the positive reinforcing effects of nicotine, such as mild euphoria, increased arousal, decreased fatigue, and relaxation (Henningfield et al. 1985). In addition, nicotine enhances the rewarding properties of environmental stimuli (Caggiula et al. 2001; Chaudhri et al.2006). Chronic nicotine use leads to neuroadaptations in the function of brain reward systems, leading to the development of nicotine dependence and resulting in aversive withdrawal effects upon abstinence from smoking (i.e., the withdrawal phase). In humans, withdrawal from nicotine produces both affective and somatic adverse effects. Adverse affective symptoms in humans are more pronounced than adverse somatic symptoms and include depressed mood, dysphoria, anxiety, irritability, difficulty concentrating, and craving (Shiffman and Jarvik 1976). The "physical" or somatic withdrawal manifestations include bradycardia, insomnia, gastrointestinal discomfort, and weight gain (Hughes et al. 1991). Avoidance of these withdrawal symptoms can help sustain the motivation to seek nicotine. After this initial withdrawal phase, prolonged abstinence from nicotine can result in a phase in which the individual is vulnerable to relapse (Brandon et al. 1998; Herd et al. 2009). Relapse can occur in response to cues/contexts associated with smoking, stressful events previously alleviated by smoking, and exposure to nicotine or tobacco smoke itself. Relapse to smoking in abstinent smokers is attributable to the learned associations between stimuli and the effects of nicotine.

\section{GLUTAMATE AND NICOTINE DEPENDENCE}

Glutamate is the major excitatory neurotransmitter in the mammalian brain, and its actions are mediated by glutamatergic receptors that can be broadly divided into fast-acting ionotropic receptors and slow-acting G-protein-coupled metabotropic receptors (Hollmann and Heinemann 1994; Conn and Pin 1997). The ionotropic receptors include $N$-methyl-D-aspartate (NMDA), amino-3-hydroxy-5-methyl-4-isoxazolepropionate (AMPA), and kainate receptors. Metabotropic glutamate (mGlu) receptors are classified into three groups (I, II, and III), depending on their signal transduction pathways, sequence homology, and pharmacological selectivity (Conn and Pin 1997). Group I (mGlu1 and $\mathrm{mGlu} 5$ ) receptors are predominantly located postsynaptically, and Group II (mGlu2 and mGlu3) and Group III (mGlu4, mGlu6, mGlu7, and mGlu8) receptors are primarily found on presynaptic terminals and on glial cells. The activation of Group II and III mGlu receptors negatively modulates glutamate release. Metabotropic glutamate receptors are critically important compared with ionotropic receptors because drugs that act on these receptors are hypothesized to subtly modulate glutamate transmission and produce fewer side effects. Furthermore, a significant body of literature has highlighted the role of mGlu receptors in drug dependence, including nicotine dependence (Kenny and Markou 2004; D'Souza and Markou 2011a). The levels of synaptic glutamate are closely regulated by transport proteins located on glial cells in the extrasynaptic space (McBean 2002; Huang and Bergles 2004). These transport proteins include the cystine-glutamate antiporter and glutamate uptake transporters (GLT1-4). 
Glutamatergic neurotransmission can be modulated by pharmacological compounds that can either block or activate the various glutamatergic receptors and transporters.

Microdialysis studies suggest that nicotine increases glutamate release in both the ventral tegmental area (VTA) and nucleus accumbens (NAcc) (Schilstrom et al. 1998; Fu et al. 2000; Reid et al. 2000). Nicotine increases glutamate release by activating excitatory $\alpha_{7} \mathrm{nACh}$ receptors located on presynaptic glutamatergic terminals (Mansvelder and McGehee 2002). $\alpha_{7}$ nACh receptors are highly permeable to calcium, and the binding of nicotine to these receptors leads to calcium-mediated glutamate release from presynaptic glutamatergic terminals (Seguela et al. 1993). Importantly, data from electrophysiological studies suggest that exposure to nicotine facilitates both glutamate release and postsynaptic AMPA/NMDA receptor-mediated neurotransmission at glutamatergic-dopaminergic synapses in the VTA (Gao et al. 2010; Mao et al. 2011). Finally, chronic nicotine self-administration increases the expression of the NR2A and NR2B NMDA receptor subunits in the prefrontal cortex and expression of the GluR2 and GluR3 AMPA receptor subunits in the VTA (Wang et al. 2007). In summary, acute nicotine administration increases the release of glutamate via excitatory $\mathrm{nACh}$ receptors located on presynaptic glutamatergic terminals. Additionally, nicotine exposure facilitates nicotine-induced presynaptic glutamate release, increases postsynaptic glutamate receptor-mediated neurotransmission, and alters the expression of ionotropic glutamate receptor expression. This nicotine-induced increase in glutamatergic neurotransmission is hypothesized to play an important role in the reinforcing effects of nicotine. The next few sections highlight the role of glutamate in nicotine-dependent behavior.

\section{Glutamate and the Reinforcing Effects of Nicotine}

Mesolimbic dopaminergic neurons that originate in the VTA are part of the neurocircuitry that mediates the reinforcing effects of most drugs of abuse, including nicotine (Fig. 1) (Wise 1987;
Koob and Volkow 2010). The activity of these dopaminergic neurons is regulated by glutamatergic inputs from different limbic, cortical, and subcortical nuclei, such as the amygdala, prefrontal cortex, lateral habenula, lateral and medial hypothalamus, ventral pallidum, medial septum, septofimbrial nucleus, and ventrolateral bed nucleus of the stria terminalis (Geisler and Zahm 2005; Geisler and Wise 2008). In addition, dopaminergic neurons in the VTA receive glutamatergic projections from brainstem structures, such as the mesopontine reticular formation, laterodorsal tegmental and pedunculopontine tegmental nucleus, cuneiform nucleus, median raphe, and superior colliculus (Geisler and Trimble 2008). Cortical and limbic nuclei play an important role in mediating motivational, emotional, and cognitive responses to rewarding stimuli.

Glutamate plays an important role in regulating nicotine-induced increases in mesolimbic dopamine. Nicotine-induced increases in dopamine in the NAcc were attenuated by systemic administration of the NMDA receptor antagonist CGP39551 and AMPA receptor antagonist ZK200775 in nicotine-naive animals (i.e., animals with no prior exposure to nicotine) (Kosowski et al. 2004). Furthermore, microinjection of the competitive NMDA receptor antagonist 2-amino-5-phosphonopentanoic acid (AP5) into the VTA attenuated nicotine-induced increases in NAcc dopamine (Schilstrom et al. 1998; Fu et al. 2000). This decrease in nicotine-induced increase in NAcc dopamine after NMDA receptor blockade was possibly caused by decreased firing of mesolimbic dopaminergic neurons (Chergui et al. 1993). Administration of the mGlu5 receptor antagonist 2-methyl-6 (phenylethynyl) pyridine (MPEP) also attenuated nicotine-induced increases in NAcc dopamine in both nicotine-naive and nicotine-experienced animals (Tronci and Balfour 2011). The mGlu2/3 receptor agonist LY379268 attenuated nicotine-induced increases in NAcc dopamine in nicotine-experienced animals only in the presence of a nicotine-associated context (Fig. 2A-C) (D’Souza et al. 2011). Interestingly, LY379268 did not attenuate the nicotine-induced increase in NAcc dopamine in nicotine- 


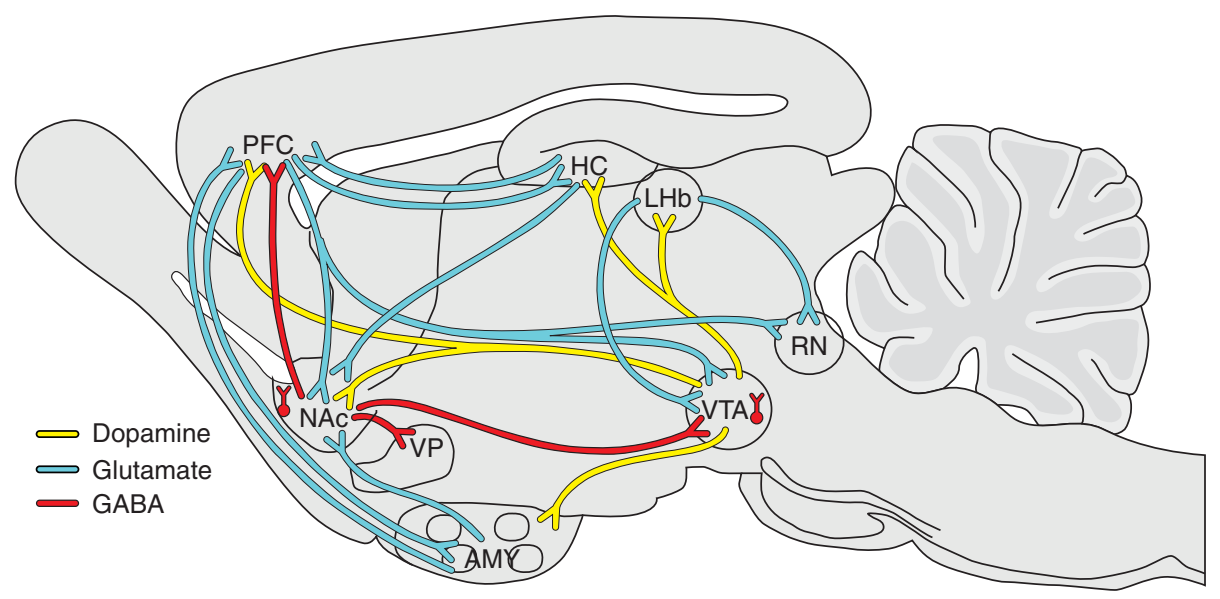

Figure 1. The figure shows a sagittal section of a rat brain that presents the regions involved in the neurochemical and behavioral effects of nicotine. Nicotine binds to nicotinic acetylcholine receptors that are located throughout the brain as auto- or heteroreceptors at presynaptic terminals that regulate the release of several neurotransmitters, including glutamate and $\gamma$-aminobutyric acid (GABA). The mesolimbic dopaminergic neurons that originate in the ventral tegmental area project to several limbic and cortical regions, including the nucleus accumbens, prefrontal cortex, amygdala, hippocampus, and habenula. The activity of these dopaminergic neurons is regulated by reciprocal glutamatergic (excitatory) and GABAergic (inhibitory) projections that originate from the aforementioned cortical and limbic brain regions. Major glutamatergic projections are depicted in blue. Dopaminergic projections that originate from the ventral tegmental area are depicted in yellow. Major GABAergic projections are depicted in red. AMY, amygdala; LHb, lateral habenula; HC, hippocampus; NAc, nucleus accumbens; PFC, prefrontal cortex; RN, raphe nucleus; VP, ventral pallidum; VTA, ventral tegmental area.

naive or nicotine-experienced animals in the absence of a nicotine-associated context. These intriguing findings are consistent with a large body of evidence that supports a role for mGlu2/3 receptors in the mediation of the context/cueinduced reinstatement of drug- and food-seeking behavior (Baptista et al. 2004; Bossert et al. 2006a,b; Liechti et al. 2007).

The most direct role for glutamate in the positive reinforcing effects of nicotine comes from intravenous nicotine self-administration studies in rats. Similar to humans, animals reliably self-administer nicotine (Corrigall and Coen 1989; Watkins et al. 1999) and provide the opportunity to assess the reinforcing and motivational effects of nicotine. The reinforcing effects of nicotine are assessed using a fixed-ratio (FR) schedule of reinforcement, and the motivational effects of nicotine are assessed using a progressive-ratio (PR) schedule (Markou 2008). In the FR schedule, animals have to press a lever a fixed number of times to obtain a single infusion of nicotine. The PR schedule involves an exponen- tial increase in the number of lever responses required to obtain each subsequent infusion of nicotine and thus reflects the motivational effects of nicotine (Markou et al. 1993).

Blockade of glutamatergic neurotransmission either by systemic administration or sitespecific microinjections of glutamate receptor antagonists into mesolimbic brain sites attenuated nicotine self-administration. Specifically, systemic administration or microinjection into the VTA of the competitive NMDA receptor antagonist LY235959 attenuated nicotine self-administration (FR5 schedule) in male Wistar rats (Kenny et al. 2009). Importantly, systemically administered LY235959 selectively decreased nicotine self-administration at low doses but did not affect food self-administration. At the highest doses tested, LY235959 attenuated both nicotine and food self-administration. Interestingly, D-cycloserine, an NMDA receptor partial agonist, also attenuated nicotine self-administration on an FR1 schedule in female SpragueDawley rats with low basal nicotine intake 

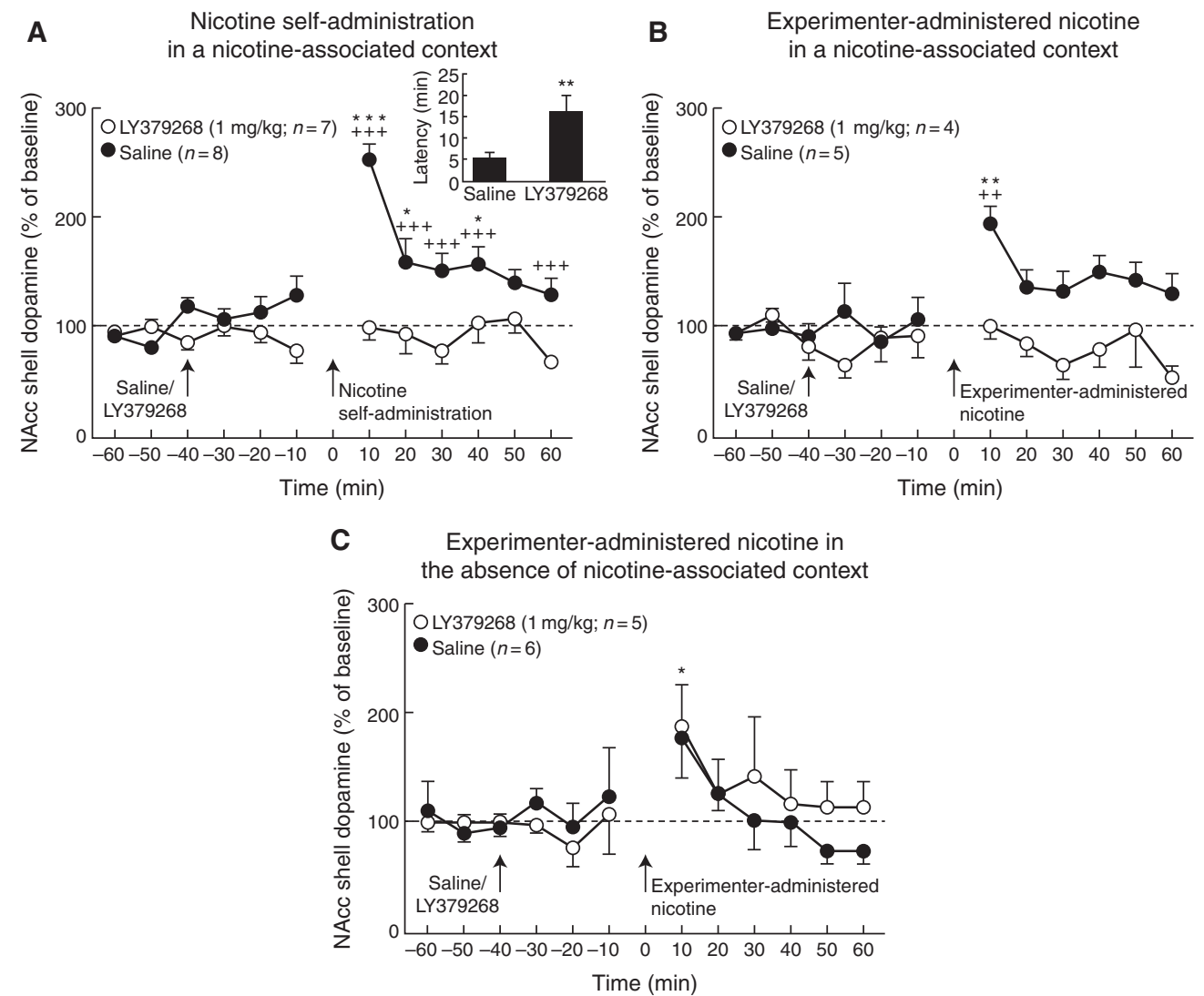

Figure 2. The figure shows the effects of the mGlu2/3 agonist LY379268 on nicotine-induced increases in NAcc dopamine. Dopamine levels (mean \pm SEM) are expressed as a percentage of baseline values. $(A)$ Systemic administration of LY379268 $(1 \mathrm{mg} / \mathrm{kg})$ attenuated the increases in NAcc shell dopamine after self-administration of a single intravenous infusion of nicotine $(0.06 \mathrm{mg} / \mathrm{kg} /$ infusion over $1 \mathrm{sec})$ in nicotine-experienced animals in a context associated with nicotine self-administration. ${ }^{*} p<0.05$, ${ }^{* * *} p<0.001$, saline-pretreated compared with their own baseline levels; ${ }^{+} p<0.05,{ }^{++} p<0.01,{ }^{++} p<0.001$, saline-pretreated compared with LY379268-pretreated animals. (Inset) Latency (mean \pm SEM) in minutes to self-administer nicotine in saline- and LY379268-pretreated animals. ${ }^{* *} p<0.01$, LY379268-pretreated group compared with saline-pretreated group. The time period between -10 and 10 depicts the time taken by the animals to self-administer nicotine and the dead volume of the probe (no samples were collected during this period). The time taken to selfadminister nicotine varied among LY379268- and saline-pretreated animals. Based on the dead volume of the tubing, sample collection was initiated $2 \mathrm{~min}$ after nicotine self-administration in all animals. (B) Systemic administration of LY379268 (1 mg/ kg, s.c.) attenuated the increases in NAcc shell dopamine after a single experimenter-administered intravenous infusion of nicotine $(0.06 \mathrm{mg} / \mathrm{kg} /$ infusion over $1 \mathrm{sec})$ in nicotineexperienced animals in a context associated with nicotine self-administration. ${ }^{* *} p<0.01$, saline-pretreated compared with their own baseline levels; ${ }^{++} p<0.01$, saline-pretreated compared with LY379268-pretreated animals. The time period between -10 and 10 depicts the dead volume of the probe, which was $2 \mathrm{~min} .(C)$ Systemic administration of LY379268 (1 mg/kg, s.c.) had no effect on the increases in NAcc shell dopamine after a single experimenter-administered intravenous infusion of nicotine $(0.06 \mathrm{mg} / \mathrm{kg} /$ infusion over $1 \mathrm{sec})$ in nicotine-experienced animals in a context never associated with nicotine self-administration. ${ }^{*} p<0.05$, salineand LY379268-pretreated compared with their respective baseline levels. The time period 2between -10 and 10 depicts the dead volume of the probe, which was $8 \mathrm{~min}$. (From D'Souza et al. 2011; reprinted, with permission, from the author.) 
(Levin et al. 2011). The effects of D-cycloserine were evaluated only in female rats, and the effects of D-cycloserine on food self-administration have not yet been evaluated. Thus, the aforementioned findings indicate that either blockade of NMDA receptors with a NMDA receptor antagonist or activation of NMDA receptor activity using a coagonist, such as D-cycloserine, decreases nicotine intake. The similar effects of the competitive NMDA receptor coagonist D-cycloserine on nicotine self-administration can be attributed to the differences in gender (male vs. female), the strain of rats used (Wistar vs. Sprague-Dawley), and the nicotine self-administration protocols (FR5 vs. FR1) in these two studies. Taken together, the data support an important role for NMDA receptors in the regulation of the reinforcing effects of nicotine.

Similarly, the mGlu5 receptor antagonist MPEP selectively attenuated nicotine self-administration without affecting food self-administration (Paterson et al. 2003; Liechti and Markou 2007; Palmatier et al. 2008). In addition, MPEP decreased the motivation to self-administer nicotine under a PR schedule, suggesting a decrease in the motivation to self-administer nicotine (Paterson and Markou 2005). Furthermore, MPEP microinfusions directly into the NAcc shell or VTA decreased nicotine self-administration (D'Souza and Markou 2011b). Interestingly, microinjections of MPEP into the NAcc shell had no effect on food self-administration, but microinjections of MPEP into the VTA had similar effects on nicotine and food self-administration. Taken together, the data from these studies suggest that mGlu5 receptors play an important role in mediating the reinforcing and motivational effects of nicotine and that the effects of MPEP are partially mediated by mGlu5 receptors in the NAcc shell and VTA.

Decreases in glutamatergic neurotransmission by systemic administration of the $\mathrm{mGlu} 2 / 3$ receptor agonist LY379268 selectively decreased nicotine self-administration in rats without affecting food self-administration, except at the highest doses tested (Fig. 3A) (Liechti et al. 2007). Microinfusion of LY379268 directly into the VTA or NAcc shell also attenuated nicotine self-administration, thus highlighting an impor- tant role for these mesolimbic nuclei in the reinforcing effects of nicotine (Fig. 3B,C). Repeated administration of LY379268 for 14 days selectively attenuated nicotine self-administration compared with food self-administration. However, rapid tolerance developed to the effects of LY379268 on nicotine self-administration. This rapid tolerance with the mGlu2/3 agonist suggests that alternative strategies to activate $\mathrm{mGlu} 2 / 3$ receptors, such as positive allosteric modulators, may be more effective than full agonists in the treatment of nicotine dependence.

Glutamate transmission can also be altered by activating the cystine-glutamate transporter (xCT) with $N$-acetylcysteine. $N$-acetylcysteine binds to the $\mathrm{xCT}$ and increases extrasynaptic glutamate levels in exchange for extracellular cystine (Baker et al. 2002). N-acetylcysteine administration attenuated nicotine self-administration, indicating that activation of the $\mathrm{xCT}$ decreased the reinforcing effects of nicotine (AM Ramirez-Niño, MS D’Souza, and A Markou, unpubl.). Importantly, the decrease in nicotine self-administration after $\mathrm{N}$-acetylcysteine administration was seen at doses that did not affect food self-administration. Repeated administration of $N$-acetylcysteine for 14 days initially reduced both nicotine and food self-administration. Rapid tolerance developed to the effects of $\mathrm{N}$-acetylcysteine on food-maintained responding, whereas the effects of $\mathrm{N}$-acetylcysteine on nicotine self-administration persisted throughout the duration of treatment.

In summary, blockade of glutamatergic neurotransmission attenuated the reinforcing and motivational effects of nicotine. Several glutamatergic receptors, such as NMDA, mGlu2/3, and mGlu5 receptors, and the xCT mediate the reinforcing effects of nicotine. Therefore, pharmacological modulation of glutamatergic neurotransmission may be a promising strategy for the promotion of smoking cessation.

\section{Glutamate and Nicotine-Induced Reward-Enhancing Effects}

The stimulation of brain reward circuits using brief electrical pulses, also known as intracranial 

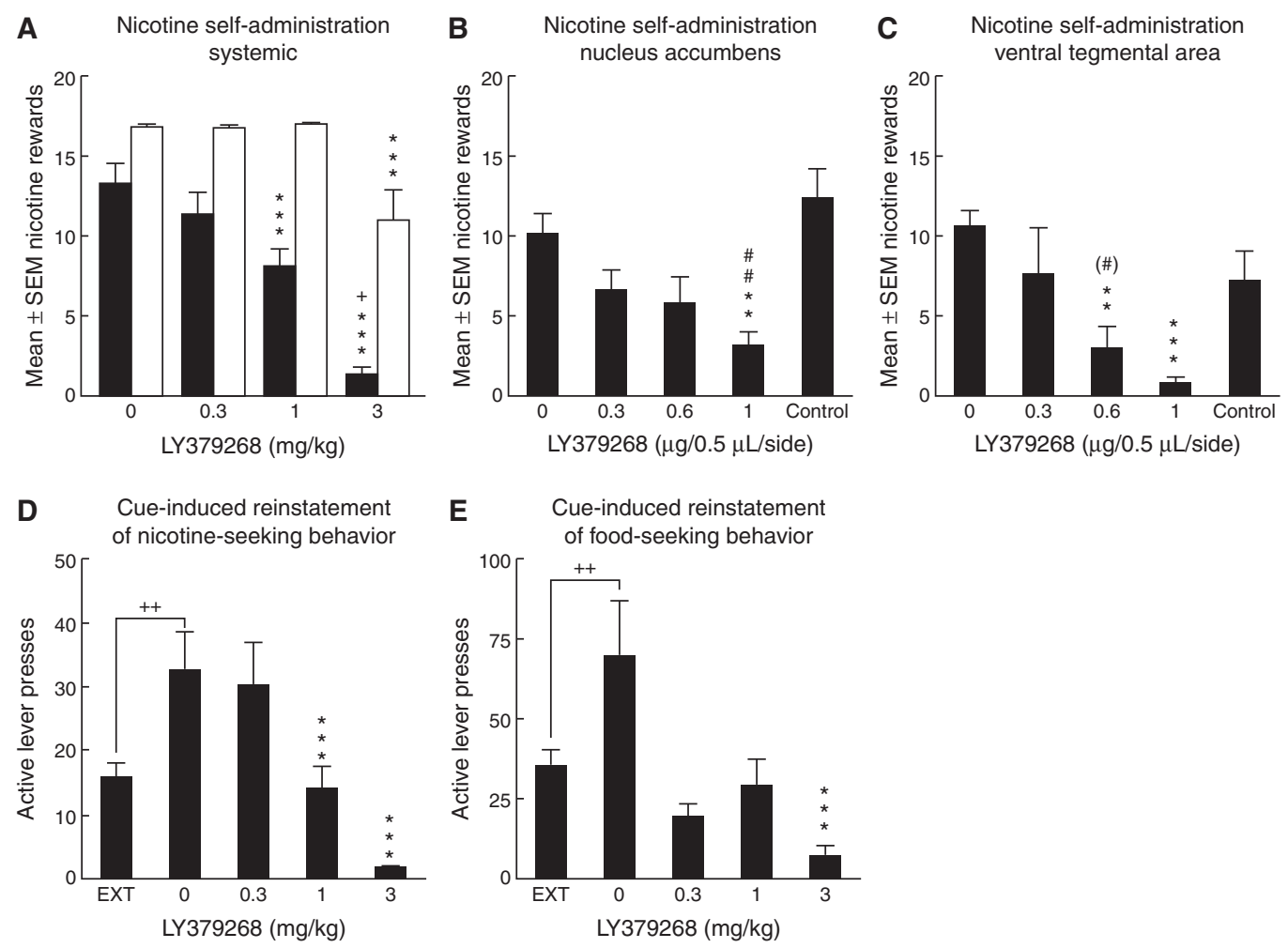

Figure 3. The figure shows the effects of the mGlu2/3 agonist LY379268 on nicotine-self-administration and nicotine-seeking behavior. (A) Systemic administration (subcutaneous [s.c.]) of the mGlu2/3 receptor agonist LY379268 decreased nicotine (black bars; $n=7$; timeout $20 \mathrm{sec}$ ) but not food (white bars; $n=8$; timeout $210 \mathrm{sec})$ self-administration except at the highest LY379268 dose $(3 \mathrm{mg} / \mathrm{kg}$, s.c. $) .{ }^{*} p<0.05,{ }^{* *} p<0.01,{ }^{* * *} p<$ 0.001 , different from $0 \mathrm{mg} / \mathrm{kg} \mathrm{LY} 379268 ;{ }^{+} p<0.05$, different from $1 \mathrm{mg} / \mathrm{kg}$ LY379268. (B) LY379268 microinjections into the nucleus accumbens (NAcc) shell $(n=9)$ attenuated nicotine self-administration. A control injection (Co; $n=9)$ of $1 \mu \mathrm{g}$ LY379268 $2 \mathrm{~mm}$ above the NAcc shell into the lateral septal nucleus had no effect on nicotine self-administration. ${ }^{\#} p<0.05,{ }^{\# \#} p<0.001$, different from control injection. (C) LY379268 microinjections into the ventral tegmental area (VTA; $n=9$ ) also decreased nicotine self-administration. A control injection (Co, $n=7$ ) of $0.6 \mu \mathrm{g}$ LY379268 $2 \mathrm{~mm}$ above the VTA into the red nucleus had no effect on nicotine self-administration. ${ }^{\#} p<0.05,{ }^{\# \#} p<0.001$, different from control injection. (D) Systemic administration of LY379268 attenuated the cue-induced reinstatement of nicotine seeking $\left(n=32\right.$; within-subject comparison). ${ }^{+} p$ $<0.05,{ }^{++} p<0.01$, different from extinction; ${ }^{*} p<0.5,{ }^{* * *} p<0.001$, different from $0 \mathrm{mg} / \mathrm{kg} \mathrm{LY379268}$. EXT, extinction; Responses, total of active lever presses, including responses during the cue presentation. (E) Systemic administration of LY379268 also attenuated the cue-induced reinstatement of food seeking ( $n=10$ per dose; between-subject comparison). ${ }^{+} p<0.05,{ }^{++} p<0.01$, different from extinction; ${ }^{*} p<0.5,{ }^{* * *} p<0.001$, different from $0 \mathrm{mg} / \mathrm{kg}$ LY379268. EXT, extinction; Responses, total of active lever presses, including responses during the cue presentation. (From Liechti et al. 2007; reprinted, with permission, from J Neurosci (C) 2007.)

self-stimulation (ICSS), is a technique used to assess the reward-enhancing effects of drugs of abuse, such as nicotine (Markou and Koob 1993). In this technique, the animal is exposed to a series of brief electric pulses that vary in current intensity, and the minimal current that main- tains self-stimulation behavior is determined. This minimal current is called the ICSS reward threshold. Psychostimulants, including nicotine, lower the ICSS threshold required to maintain self-stimulation behavior (Kornetsky and Esposito 1979; Harrison et al. 2002). 
Pharmacological blockade of glutamatergic neurotransmission attenuated the nicotine-induced lowering of ICSS thresholds. For example, the NMDA receptor antagonist LY235959 reversed the nicotine-induced lowering of reward thresholds (Kenny et al. 2009). Importantly, LY235959 did not affect brain reward thresholds when administered alone. These data suggest that NMDA receptors play an important role in the reward-enhancing effects of nicotine. The mGlu5 receptor antagonist MPEP and mGlu2/3 agonist LY314582 also attenuated the reward-enhancing effects of nicotine (Harrison et al. 2002). Interestingly, administration of either MPEP or LY314582 alone elevated brain reward thresholds, indicating that these compounds have an opposite effect to nicotine, rather than directly blocking or reversing the reward-enhancing effects of nicotine. Consistent with this interpretation, MPEP and another more selective mGlu5 receptor antagonist, MTEP, did not block the reward-enhancing effects of nicotine measured using an operant procedure in which animals received experimenter-administered nicotine in response to lever pressing for a visual stimulus (Palmatier et al. 2008). The ICSS findings suggest that NMDA-mediated neurotransmission attenuates the nicotine-induced facilitation of brain reward, whereas glutamatergic neurotransmission via mGlu5 and mGlu2/3 receptors appears to have an opposite effect in reward function compared with nicotine.

\section{Glutamate and the Conditioned Rewarding Effects of Nicotine}

Environmental cues associated with nicotine play an important role in the maintenance of nicotine intake in humans and animals (Caggiula et al. 2001; Le Foll and Goldberg 2005a). The positive rewarding effects of nicotine play an important role in the associative learning between nicotine and cues/contexts that predict nicotine administration. The conditioned rewarding effects of nicotine and underlying neural substrates can be studied using the conditioned place preference (CPP) procedure.
Most commonly, two chambers with distinct characteristics (e.g., color, texture, and flooring) are used in CPP studies. One of the two chambers is associated with nicotine during a training session and is called the drug-paired chamber. In another temporally distinct training session, the animals are treated with vehicle and placed in the other chamber, referred to as the saline-paired chamber. The repeated pairing of the drug-paired chamber with the rewarding effects of nicotine over time results in a preference for the drug-paired chamber over the saline-paired chamber during a test session conducted in the absence of the drug. Several studies have shown nicotine-induced CPP in rodents (Fudala et al. 1985; Shoaib et al. 1994; Risinger and Oakes 1995; McGeehan and Olive 2003; Le Foll and Goldberg 2005b; Grabus et al. 2006).

Glutamate plays an important role in the conditioned rewarding effects of nicotine. Selective knockout of NMDA receptors located on VTA dopaminergic neurons in mice attenuated the acquisition of nicotine-induced CPP (Wang et al. 2010). Consistent with these data, the glycine site partial agonist 1-aminocyclopropanecarboxylic acid (ACPC), which reduces NMDA receptor-mediated neurotransmission, attenuated the acquisition and expression of nicotine-induced CPP (Papp et al. 2002). These data support a role for NMDA receptors, particularly those in the VTA, in the conditioned rewarding effects of nicotine. The mGlu5 receptor antagonist MPEP also attenuated nicotineinduced CPP (Yararbas et al. 2010; but also see McGeehan and Olive 2003). Consistent with this finding, MPEP also decreased conditioned locomotor activity evoked by pairing nicotine with a specific environment (Tronci et al. 2010). Interestingly, one study reported that MPEP facilitated nicotine-induced CPP, resulting in a leftward shift of the minimum dose of nicotine required to induce CPP (Rutten et al. 2011). The facilitation of nicotine-induced CPP is surprising, considering that MPEP when administered alone elevated reward thresholds in the ICSS procedure. The conflicting data with regard to MPEP in nicotine-induced CPP could possibly be attributable to differences in the 
strains of animals used, doses, and modes of MPEP administration and design used to show nicotine-induced CPP. In summary, the above data suggest that glutamate plays an important role in the conditioned rewarding effects of nicotine, and these effects are partially mediated by activation of postsynaptic NMDA and mGlu5 receptors.

\section{Glutamate and Nicotine Seeking}

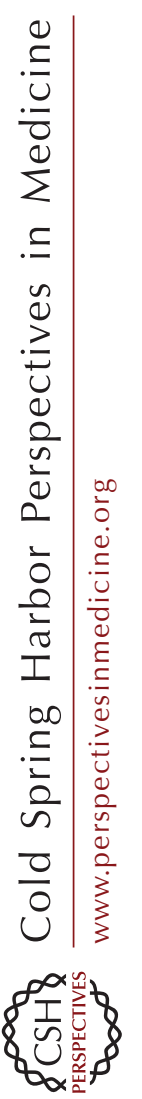

As mentioned above, abstinent smokers are susceptible to relapse when exposed to either stimuli previously associated with smoking or stressful stimuli whose effects were previously alleviated by smoking or both. Similarly, experimental animals exposed to cues or contexts previously associated with nicotine self-administration show reinstatement of nicotine-seeking behavior even after the extinction of nicotine self-administration behavior (Paterson et al. 2005; Dravolina et al. 2007). This reinitiation of nicotine-seeking behavior in animals after a period of extinction training is a putative model of relapse in humans (Markou et al. 1993; Shaham et al. 2003). The reinstatement of nicotineseeking behavior in animals is also seen after exposure to nicotine (Dravolina et al. 2007).

The mGlu5 receptor antagonist MPEP attenuated the cue-induced reinstatement of nicotine seeking but not food seeking (Bespalov et al. 2005). In contrast, the mGlu2/3 agonist LY379268 attenuated the cue-induced reinstatement of both nicotine and food seeking (Liechti et al. 2007). $N$-acetylcysteine also attenuated the cue-induced reinstatement of both nicotine and food seeking, supporting a role for the cystine-glutamate exchanger in cue-induced nicotine-seeking behavior (AM Ramirez-Niño, MS D'Souza, and A Markou, unpubl.). Altogether, these results show an important role for glutamate in the conditioned behavioral responses to cues and contexts associated with nicotine. However, the blockade of cue-induced food seeking suggests that the glutamatergic compounds tested so far attenuate conditioned behavioral responses, regardless of the reinforcer. Although this attenuation of cue-induced foodseeking behavior may be an undesirable effect in most situations, it may be advantageous in the case of the medications being developed to prevent relapse in smokers. Because smokers who abstain from smoking often experience extreme food cravings that result in undesired weight gain (Friedman and Siegelaub 1980), the ability to block cue-induced food seeking may be a useful property of medications intended to prevent relapse in abstinent smokers. Generally, the fact that these compounds block both nicotine and food seeking may indicate a critical role for these receptors in all conditioned behaviors.

\section{Glutamate and Nicotine Withdrawal}

The expression and function of glutamate receptors is altered during early withdrawal in animals chronically exposed to nicotine. Specifically, the expression of the NR2A, NR2B, and GluR2 subunits decreased in the prefrontal cortex (Kenny et al. 2009). However, the same study found increased expression of the NR1, NR2A, NR2B, GluR1, and GluR2 subunits in the amygdala. The expression of the NR2A and GluR1 subunits was also increased in the VTA and NAcc, respectively. Furthermore, down-regulation of mGlu2/3 receptor function in the VTA, NAcc, prefrontal cortex, amygdala, hippocampus, and hypothalamus was seen during early withdrawal after a period of chronic nicotine self-administration (Liechti et al. 2007). mGlu2/3 receptors are located on presynaptic glutamatergic terminals and negatively regulate synaptic glutamate levels. Therefore, the downregulation of $m G l u 2 / 3$ receptor function during early withdrawal suggests the development of a hypoglutamatergic state. Finally, downregulation of the $\mathrm{xCT}$ and glutamate transporter (GLT-1) in the NAcc was also reported during early withdrawal after a period of chronic nicotine self-administration (Knackstedt et al. 2009). Both xCT and GLT-1 play an important role in maintaining extracellular glutamate levels, and down-regulation of these transporters suggests compensatory changes in response to decreased synaptic glutamate levels during early withdrawal. The above data suggest that withdrawal from nicotine after a period of nicotine self-administration results in the development 
of a hypoglutamatergic state that is characterized by: (1) the increased expression of postsynaptic glutamatergic receptors, such as NMDA and AMPA receptors; (2) down-regulation in the function of presynaptic autoreceptors, such as mGlu2/3 receptors; and (3) down-regulation in the function of extrasynaptic glutamatergic transporters, such as xCT and GLT-1.

Withdrawal from nicotine produces both somatic and affective disturbances in animals. The somatic withdrawal signs seen in rodents include rearing, jumping, shakes, abdominal constrictions, chewing, scratching, and facial tremors (Watkins et al. 2000; Malin et al. 2006). In animals, the affective depression-like aspects of nicotine withdrawal can be measured using the ICSS procedure and are reflected by elevations in reward thresholds (Epping-Jordan et al. 1998; Watkins et al. 2000). Importantly, the AMPA receptor antagonist NBQX elevated brain reward thresholds in nicotine-dependent rats, similar to the reward thresholds seen after administration of nACh receptor antagonists in nicotinedependent animals (Kenny et al. 2003). This finding suggests that AMPA receptors are involved in the affective manifestations seen during nicotine withdrawal. Furthermore, the mGlu5 receptor antagonist MPEP exacerbated brain reward deficits and somatic signs associated with nicotine withdrawal (Liechti and Markou 2007). The same study also showed that administration of the $\mathrm{mGlu} 2 / 3$ receptor agonist LY379268 did not worsen brain reward thresholds during nicotine withdrawal. A possible reason for the lack of effects of the mGlu2/3 receptor agonist during nicotine withdrawal could be the down-regulation of $\mathrm{mGlu} 2 / 3$ receptor function. In summary, nicotine withdrawal is hypothesized to be associated with the development of a hypoglutamatergic state, and strategies that increase glutamate transmission may help reverse the affective and somatic signs of nicotine withdrawal.

\section{GABA AND NICOTINE DEPENDENCE}

GABA is the major inhibitory neurotransmitter in the brain. Endogenously released GABA acts either via ionotropic $\left(\mathrm{GABA}_{\mathrm{A}}\right.$ and $\left.\mathrm{GABA}_{\mathrm{C}}\right)$ or metabotropic $\left(\mathrm{GABA}_{\mathrm{B}}\right)$ receptors. The binding of GABA to $\mathrm{GABA}_{\mathrm{A}}$ or $\mathrm{GABA}_{\mathrm{C}}$ receptors allows the entry of $\mathrm{Cl}^{-}$ions, resulting in neuron hyperpolarization and ultimately the decreased firing of these neurons. In addition to GABA, $\mathrm{GABA}_{\mathrm{A}}$ but not $\mathrm{GABA}_{\mathrm{C}}$ receptors have modulatory binding sites for barbiturates, benzodiazepines, neurosteroids, and ethanol. Apart from these pharmacological differences between $\mathrm{GABA}_{\mathrm{A}}$ and $\mathrm{GABA}_{\mathrm{C}}$ receptors, structural differences also exist that are beyond the scope of this review (see Bormann 2000). In contrast to $\mathrm{GABA}_{\mathrm{A}}$ and $\mathrm{GABA}_{\mathrm{C}}$ receptors, $\mathrm{GABA}_{\mathrm{B}}$ receptors couple to $\mathrm{Ca}^{2+}$ and $\mathrm{K}^{+}$ion channels via G-proteins and second messengers. Evidence suggests that the effects of nicotine on the mesocorticolimbic dopaminergic system are regulated primarily by $\mathrm{GABA}_{\mathrm{B}}$ receptors in the VTA (Amantea and Bowery 2004). Endogenous GABA is metabolized by GABA transaminase. Therefore, GABA neurotransmission can be increased by compounds that enhance the activity of GABA receptors or inhibit the breakdown of GABAvia inhibition of GABA transaminase.

Nicotine induces GABA release by binding to excitatory nACh receptors located on presynaptic GABA neurons. The cellular mechanism by which the activation of $\mathrm{nACh}$ receptors results in GABA release is not clearly understood. Recent work showed that activation of $\mathrm{nACh}$ receptors on GABAergic terminals depolarized cells, resulting in the opening of T-type $\mathrm{Ca}^{2+}$ channels and leading to GABA release (Tang et al. 2011). This study was conducted in hippocampal perisomatic GABA interneurons that contain $\alpha_{3} \beta_{4}$-containing $\mathrm{nACh}$ receptors. It is not known whether the same mechanism is involved in the release of GABA from neurons located in the mesolimbic region.

The composition of the subtype of $\mathrm{nACh}$ receptors located on GABAergic neurons has not been fully identified. Existing evidence suggests the presence of $\mathrm{nACh}$ receptors composed of $\alpha_{3} \beta_{4^{-}}, \alpha_{4} \beta_{2^{-}}$, or $\alpha_{6} \beta_{2}$-containing $n A C h$ receptors on GABAergic neurons that terminate on mesolimbic dopaminergic neurons (Mansvelder et al. 2002; Yang et al. 2011). Knowledge of the composition of $\mathrm{nACh}$ receptors on GABA neurons is essential because $\mathrm{nAChR}$ composition 
determines the rate at which nACh receptors undergo desensitization or functional inactivation on exposure to nicotine (Fenster et al. 1999; Quick and Lester 2002). The desensitization of nACh receptors can result in decreased GABA release and consequently decreased inhibition of mesolimbic dopaminergic neurons, thus facilitating the nicotine-induced excitation of mesolimbic dopaminergic neurons. The desensitization of $\beta_{2}$-containing $\mathrm{nACh}$ receptors on GABAergic interneurons may be involved in the decreased GABA-mediated inhibition of dopaminergic neurons (Mansvelder et al. 2002). A recent study reported that decreased GABA release on repeated nicotine exposure was mediated by $\alpha_{6} \beta_{2}$-containing nACh receptors located on presynaptic GABA neurons in the VTA (Tang et al. 2011). Importantly, the latter study found decreased acetylcholine-induced GABA release after nicotine exposure. Nicotine-induced alterations in $\mathrm{GABA}_{\mathrm{B}}$ receptor function or expression could also be a possible mechanism by which chronic nicotine exposure reduces GABAergic transmission. Evidence for this hypothesis, however, is mixed. For example, both the GABA structural analog $\gamma$-vinyl GABA (GVG) and $\mathrm{GABA}_{\mathrm{B}}$ agonist CGP44532 did not affect brain reward thresholds in the ICSS procedure in saline- or nicotine-treated rats, whereas the highest dose of each drug elevated thresholds in both groups of rats (Paterson et al. 2005). Additionally, CGP44532 microinfusions into the VTA elevated thresholds equally in both saline- and nicotine-treated groups, indicating that prolonged nicotine exposure did not alter the $\mathrm{GABA}_{\mathrm{B}}$-mediated regulation of brain reward function. Altogether, these data suggest that nicotine exposure does not alter the $\mathrm{GABA}_{B}$ receptor-mediated regulation of brain reward function. Furthermore, changes in $G_{A B A}$ receptor expression or $G_{A B A}$ mRNA levels have not been observed after chronic nicotine treatment. No alterations in $\mathrm{GABA}_{\mathrm{B}}$-G-protein coupling have been reported in the VTA after chronic nicotine treatment. However, one study found reduced efficacy of the $\mathrm{GABA}_{\mathrm{B}}$ receptor agonist baclofen to decrease electrically stimulated $\left[{ }^{3} \mathrm{H}\right]$ dopamine release in a slice preparation of VTA dopamine neurons after chronic nicotine treatment (Amantea and Bowery 2004). This finding suggests that chronic nicotine treatment alters the function of $\mathrm{GABA}_{B}$ receptors. $\mathrm{GABA}_{\mathrm{B}}$-G-protein coupling is also altered in other brain regions, such as the NAcc and prefrontal cortex, after chronic nicotine treatment (Amantea et al. 2004). However, these in vitro changes may not have functional significance, at least in terms of reward function (see above). These differences in the literature may be attributable to differences in nicotine exposure and the methods used to assess $\mathrm{GABA}_{\mathrm{B}}$ receptor function. In summary, GABAergic neurons provide important inhibitory inputs to dopaminergic neurons. Acute nicotine administration increases GABA release by binding to excitatory presynaptic nACh receptors located on GABA neurons. Repeated nicotine administration decreases the GABA regulation of mesolimbic dopaminergic neurons by desensitizing nACh receptors or decreasing $\mathrm{GABA}_{\mathrm{B}}$ receptor function or both, although the latter possibility is not supported by behavioral data (see above). The role of GABA in nicotine dependence has been studied in behavioral models using pharmacological compounds that either increase or decrease GABA neurotransmission. In the following sections, the role of GABA in nicotinedependent behavior is discussed.

\section{GABA and the Reinforcing Effects of Nicotine}

GABA plays an important role in regulating mesolimbic dopaminergic neurons that partially mediate the reinforcing effects of nicotine and other drugs of abuse. These mesolimbic dopaminergic neurons receive extensive local and external GABAergic inputs. The local inputs are mainly derived from local interneurons, whereas the external inputs originate from distant nuclei, such as the NAcc, ventral pallidum, and pedunculopontine tegmental nucleus (Kalivas and O'Brien 2008).

Systemic administration of compounds that enhance GABA neurotransmission attenuate nicotine-induced increases in mesolimbic dopamine. For example, GVG, an inhibitor of GABA transaminase, dose-dependently attenuated the 
nicotine-induced increases in NAcc dopamine in both naive and nicotine-treated rats (Dewey et al. 1999). Baclofen, a GABA $\mathrm{B}$ receptor agonist, dosedependently decreased the nicotine-induced increases in NAcc shell (Fadda et al. 2003). Altogether, the data support a role for GABA and $G_{A B A}$ receptors in the regulation of nicotine-induced increases in NAcc dopamine.

Consistent with the above effects on nicotine-induced increases in NAcc dopamine, GVG also attenuated nicotine self-administration (Paterson and Markou 2002). Furthermore, $\mathrm{GABA}_{\mathrm{B}}$ receptor agonists, such as baclofen and CGP44532, attenuated nicotine self-administration (Paterson et al. 2004). Importantly, the decrease in nicotine self-administration was also seen after repeated administration of CGP44532 for 14 days, indicating little tolerance to this effect of the $\mathrm{GABA}_{\mathrm{B}}$ receptor agonist (Paterson et al. 2005). Furthermore, microinjections of baclofen or CGP44532 into either the NAcc shell or VTA or pedunculopontine tegmental nucleus decreased nicotine self-administration (Corrigall et al. 2000, 2001). A preliminary clinical study reported reductions in the number of cigarettes smoked per day in smokers treated with baclofen (Franklin et al. 2009). In addition to $\mathrm{GABA}_{\mathrm{B}}$ receptor agonists, $\mathrm{GABA}_{\mathrm{B}}$ receptor positive allosteric modulators, such as CGP7930 and BHF177, decreased nicotine selfadministration under both FR and PR schedules in rats at doses that did not affect behaviors reinforced by food (Fig. 4A) (Paterson et al. 2008). The decrease in nicotine self-administration under both FR and PR schedules suggests that these compounds attenuate both the reinforcing effects of nicotine and the motivation to self-administer nicotine. Moreover, repeated administration of BHF177 for 14 days selectively attenuated nicotine self-administration compared with food-maintained responding.

Overall, $\mathrm{GABA}_{\mathrm{B}}$ receptor positive allosteric modulators have more subtle effects than $\mathrm{GABA}_{\mathrm{B}}$ receptor agonists (Guery et al. 2007; Paterson et al. 2008). Importantly, $\mathrm{GABA}_{\mathrm{B}}$ receptor positive allosteric modulators either do not induce or have minimal motor-impairing effects compared with $\mathrm{GABA}_{\mathrm{B}}$ receptor agonists. Finally, $\mathrm{GABA}_{\mathrm{B}}$ receptor positive allosteric modulators, in contrast to $\mathrm{GABA}_{\mathrm{B}}$ receptor agonists, do not affect responding for nondrug rewards, such as food, in animal models. Thus, $\mathrm{GABA}_{\mathrm{B}}$ receptors play an important role in mediating the reinforcing effects of nicotine, and $\mathrm{GABA}_{\mathrm{B}}$ receptor positive allosteric modulators may help promote smoking cessation and have a better side-effect profile than full $\mathrm{GABA}_{\mathrm{B}}$ receptor agonists.

\section{GABA and Nicotine-Induced Enhancement of Brain Reward Function}

GABA transmission via $\mathrm{GABA}_{\mathrm{B}}$ receptors partially mediates the nicotine-induced enhancement of the reinforcing effects of stimuli assessed using the ICSS procedure. $G_{A B A}$ receptor activation via administration of either CGP44532 or BHF 177 attenuated the threshold-lowering effects of acute nicotine (Paterson et al. 2008). However, brain reward thresholds were elevated when CGP44532 or BHF177 was administered alone. Importantly, these threshold elevations were seen at doses that did not attenuate nicotine self-administration. These data suggest that attenuation of the nicotineinduced lowering of reward thresholds may simply be attributable to opposite effects of $\mathrm{GABA}_{\mathrm{B}}$ receptor activation and nicotine on brain reward thresholds (i.e., these compounds may "neutralize" the effects of nicotine rather than reverse the rewarding effects of nicotine, similar to what is seen with an mGlu5 receptor antagonist and mGlu2/3 receptor agonist; see above). Notably, compared with CGP44532, BHF177induced threshold elevations were seen at doses that were much higher than those required to block the nicotine-induced lowering of ICSS thresholds and nicotine self-administration. These data suggest that the positive modulation of $\mathrm{GABA}_{\mathrm{B}}$ receptors may reduce the nicotineinduced enhancement of brain reward function, even if the effects do not involve a direct and specific pharmacodynamic interaction.

\section{GABA and Nicotine-Induced Conditioned Behavioral Responses}

GABA also plays a role in nicotine-induced CPP. 1R, 4S-4-amino-cyclopent-2-ene-carboxylic 
Role of GABA and Glutamate
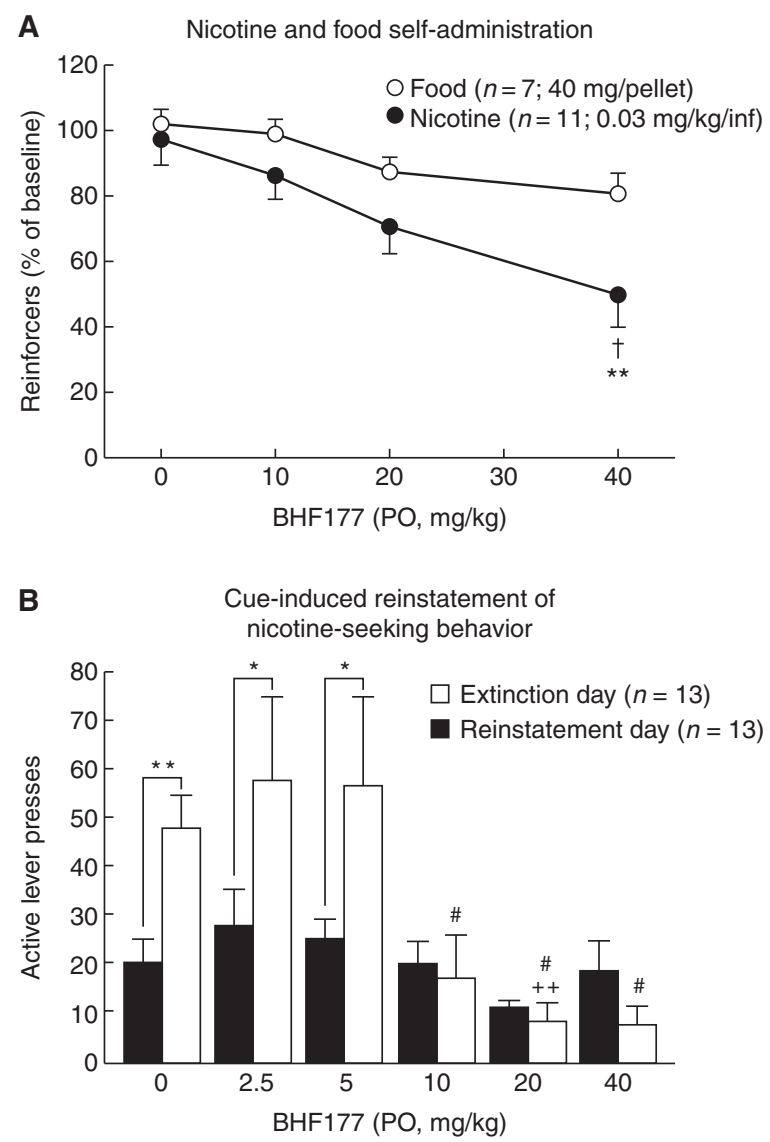

Figure 4. The figure shows the effects of the $\mathrm{GABA}_{\mathrm{B}}$ receptor positive modulator BHF177 on nicotine selfadministration and the cue-induced reinstatement of nicotine-seeking behavior. (A) Systemic oral administration of BHF177 attenuated nicotine self-administration without affecting food-maintained responding assessed under a fixed-ratio schedule of reinforcement. The graph shows nicotine- and food-maintained responding expressed as a percentage of baseline number of rewards earned (mean \pm SEM) and as the number of reinforcers earned (left ordinal axis). ${ }^{* *} p<0.01$, significant differences compared with nicotine self-administration after vehicle administration; ${ }^{\dagger} p<0.05$, significant difference compared with $10 \mathrm{mg} / \mathrm{kg}$ BHF177. inf, infusion. (Panel $A$ is from Paterson et al. 2008; reprinted, with permission, from the American Society for Pharmacology and Experimental Therapeutics (C) 2008.) (B) Administration of BHF177 attenuated the cue-induced reinstatement of nicotine-seeking behavior. The data are expressed as the number of active lever presses during the extinction session (i.e., the last extinction session of the three conducted between reinstatement sessions) that preceded each reinstatement session (white bars) and reinstatement session (black bars). ${ }^{*} p<0.05,{ }^{* *} p<0.01$, significant differences in responding between the reinstatement day and preceding extinction day; ${ }^{\# \#} p<0.001$, significant differences in responding between the 10,20 , and $40 \mathrm{mg} / \mathrm{kg}$ doses compared with vehicle and the 2.5 and $5 \mathrm{mg} / \mathrm{kg}$ doses; ${ }^{++} p<0.01$, significant difference between the 5 and $20 \mathrm{mg} / \mathrm{kg}$ doses. (Panel $B$ is from Vlachou et al. 2011b; reprinted, with permission, from Springer (C) 2011.)

acid (ACC), an irreversible inhibitor of GABA transaminase, attenuated the expression of nicotine-induced CPP in rats (Ashby et al. 2002). In addition, GVG blocked both the acquisition and expression of nicotine-induced CPP (Dewey et al. 1999). The $\mathrm{GABA}_{B}$ receptor agonist baclofen also attenuated the expression of nicotineinduced CPP (Fattore et al. 2009). The $\mathrm{GABA}_{\mathrm{B}}$ receptor positive allosteric modulator GS39783 attenuated the development but not expression 
M.S. D'Souza and A. Markou

of nicotine-induced CPP (Mombereau et al. 2007). These data support a role for $\mathrm{GABA}_{\mathrm{B}}$ receptors in nicotine-induced reward and conditioned behavioral responses.

\section{GABA and Cue-Induced Reinstatement of Nicotine-Seeking Behavior}

The $\mathrm{GABA}_{\mathrm{B}}$ receptor agonists baclofen and CGP44532 also blocked the cue-induced reinstatement of nicotine-seeking behavior (Paterson et al. 2005). Importantly, baclofen did not block the cue-induced reinstatement of food seeking, suggesting that the effects of baclofen were specific for the nicotine-associated conditioned motivational behavioral responses. The $\mathrm{GABA}_{\mathrm{B}}$ receptor positive allosteric modulator BHF177 also attenuated cue-induced nicotine seeking without affecting food seeking (Fig. 4B) (Vlachou et al. 2011a). These findings suggest that the activation of $\mathrm{GABA}_{\mathrm{B}}$ receptors may be useful in attenuating relapse to nicotine seeking in abstinent human smokers.

\section{GABA and Nicotine Withdrawal}

The role of GABA in nicotine withdrawal is not entirely clear. The activation of $\mathrm{GABA}_{\mathrm{B}}$ receptors by administering either the $\mathrm{GABA}_{\mathrm{B}}$ receptor agonist CGP44532 or $\mathrm{GABA}_{\mathrm{B}}$ receptor positive allosteric modulator BHF177 elevated ICSS thresholds during nicotine withdrawal in animals, indicating an exacerbation of the anhedonia-like aspects of nicotine withdrawal (Vlachou et al. 2011b). Interestingly, the $\mathrm{GABA}_{\mathrm{B}}$ receptor antagonist CGP56433 also exacerbated the anhedonia-like effects of nicotine withdrawal (Vlachou et al. 2011b). It is not clear why both activation and blockade of $\mathrm{GABA}_{\mathrm{B}}$ receptors resulted in a worsening of the anhedonia-like effects of nicotine withdrawal. The differential effects of these compounds at presynaptic hetero- and autoreceptors vs. postsynaptic $\mathrm{GABA}_{\mathrm{B}}$ receptors may have contributed to these findings. Thus, $\mathrm{GABA}_{\mathrm{B}}$ receptors are critically involved in the affective aspects of nicotine withdrawal, and the administration of compounds that modulate $\mathrm{GABA}_{\mathrm{B}}$-mediated transmission exacerbated the affective aspects of nicotine withdrawal.

\section{CONCLUSION}

Both glutamate and GABA play important roles in the reinforcing effects of nicotine and development of nicotine dependence. Chronic nicotine exposure facilitates excitatory glutamate neurotransmission, and repeated nicotine exposure attenuates inhibitory GABA neurotransmission. Overall, the preclinical data presented in this article strongly suggest that the substrates, such as receptors, transporters, or enzymes that regulate the actions of glutamate and GABA, may be useful targets for the treatment of nicotine dependence. Currently, medications that target either glutamate or GABA neurotransmission are being evaluated in human smokers. The next generation of glutamate- or GABA-based smoking cessation medications may have better efficacy and fewer adverse effects than the currently approved smoking cessation medications.

\section{ACKNOWLEDGMENTS}

This work is supported by NIH research grants 1R01DA11946, R01DA232090, and 2U19DA 026838 to A.M. M.S.D. is supported by fellowship 19FT-0045 from the Tobacco-Related Disease Research Program of the State of California. A.M. has received contract research support from Intracellular Therapeutics, Inc., Bristol-Myers Squibb Co., F. Hoffman-La Roche, Pfizer, and Astra-Zeneca and honoraria/consulting fees from Abbott GmbH and Company, AstraZeneca, and Pfizer during the past 3 years. A.M. has a patent application on the use of metabotropic glutamate compounds for the treatment of nicotine dependence. M.S.D. reports no financial conflicts of interest.

\section{REFERENCES}

Agboola S, McNeill A, Coleman T, Leonardi Bee J. 2010. A systematic review of the effectiveness of smoking relapse prevention interventions for abstinent smokers. Addiction 105: 1362-1380.

Amantea D, Bowery NG. 2004. Reduced inhibitory action of a $\mathrm{GABA}_{\mathrm{B}}$ receptor agonist on $\left[{ }^{3} \mathrm{H}\right]$-dopamine release from rat ventral tegmental area in vitro after chronic nicotine administration. BMC Pharmacol 4: 24.

Amantea D, Tessari M, Bowery NG. 2004. Reduced G-protein coupling to the $\mathrm{GABA}_{\mathrm{B}}$ receptor in the nucleus 
accumbens and the medial prefrontal cortex of the rat after chronic treatment with nicotine. Neurosci Lett 355: $161-164$

Ashby CR Jr, Paul M, Gardner EL, Gerasimov MR, Dewey SL, Lennon IC, Taylor SJ. 2002. Systemic administration of $1 R, 4 S$-4-amino-cyclopent-2-ene-carboxylic acid, a reversible inhibitor of GABA transaminase, blocks expression of conditioned place preference to cocaine and nicotine in rats. Synapse 44: 61-63.

Baker DA, Shen H, Kalivas PW. 2002. Cystine/glutamate exchange serves as the source for extracellular glutamate: Modifications by repeated cocaine administration. Amino Acids 23: 161-162.

Baptista MA, Martin-Fardon R, Weiss F. 2004. Preferential effects of the metabotropic glutamate $2 / 3$ receptor agonist LY379268 on conditioned reinstatement versus primary reinforcement: Comparison between cocaine and a potent conventional reinforcer. J Neurosci 24: 47234727.

Benowitz NL. 2010. Nicotine addiction. N Engl J Med 362: 2295-2303.

Bespalov AY, Dravolina OA, Sukhanov I, Zakharova E, Blokhina E, Zvartau E, Danysz W, van Heeke G, Markou A. 2005. Metabotropic glutamate receptor (mGluR5) antagonist MPEP attenuated cue- and schedule-induced reinstatement of nicotine self-administration behavior in rats. Neuropharmacology 49: 167-178.

Bormann J. 2000. The "ABC" of GABA receptors. Trends Pharmacol Sci 21: 16-19.

Bossert JM, Gray SM, Lu L, Shaham Y. 2006a. Activation of group II metabotropic glutamate receptors in the nucleus accumbens shell attenuates context-induced relapse to heroin seeking. Neuropsychopharmacology 31: 21972209.

Bossert JM, Poles GC, Sheffler-Collins SI, Ghitza UE. 2006b. The mGluR2/3 agonist LY379268 attenuates contextand discrete cue-induced reinstatement of sucrose seeking but not sucrose self-administration in rats. Behav Brain Res 173: 148-152.

Brandon TH, Lazev AB, Juliano LM. 1998. Very delayed smoking relapse warrants research attention. Psychol Rep 83: 72-74.

Caggiula AR, Donny EC, White AR, Chaudhri N, Booth S, Gharib MA, Hoffman A, Perkins KA, Sved AF. 2001. Cue dependency of nicotine self-administration and smoking. Pharmacol Biochem Behav 70: 515-530.

Centers for Disease Control and Prevention. 2011. Current cigarette smoking prevalence among working adults: United States, 2004-2010. MMWR Morb Mortal Wkly Rep 60: 1305-1309.

Changeux JP. 2010. Nicotine addiction and nicotinic receptors: Lessons from genetically modified mice. Nat Rev Neurosci 11: 389-401.

Chaudhri N, Caggiula AR, Donny EC, Palmatier MI, Liu X, Sved AF. 2006. Complex interactions between nicotine and nonpharmacological stimuli reveal multiple roles for nicotine in reinforcement. Psychopharmacology (Berl) 184: 353-366.

Chergui K, Charlety PJ, Akaoka H, Saunier CF, Brunet JL, Buda M, Svensson TH, Chouvet G. 1993. Tonic activation of NMDA receptors causes spontaneous burst discharge of rat midbrain dopamine neurons in vivo. Eur J Neurosci 5: $137-144$

Conn PJ, Pin JP. 1997. Pharmacology and functions of metabotropic glutamate receptors. Annu Rev Pharmacol Toxicol 37: 205-237.

Corrigall WA, Coen KM. 1989. Nicotine maintains robust self-administration in rats on a limited-access schedule. Psychopharmacology (Berl) 99: 473-478.

Corrigall WA, Coen KM, Adamson KL, Chow BL, Zhang J. 2000. Response of nicotine self-administration in the rat to manipulations of $\mu$-opioid and $\gamma$-aminobutyric acid receptors in the ventral tegmental area. Psychopharmacology (Berl) 149: 107-114.

Corrigall WA, Coen KM, Zhang J, Adamson KL. 2001. GABA mechanisms in the pedunculopontine tegmental nucleus influence particular aspects of nicotine self-administration selectively in the rat. Psychopharmacology (Berl) 158: 190-197.

D’Souza MS, Markou A. 2011a. Neuronal mechanisms underlying development of nicotine dependence: Implications for novel smoking-cessation treatments. Addict Sci Clin Pract 6: 4-16.

D'Souza MS, Markou A. 2011b. Metabotropic glutamate receptor 5 antagonist 2-methyl-6-(phenylethynyl)pyridine (MPEP) microinfusions into the nucleus accumbens shell or ventral tegmental area attenuate the reinforcing effects of nicotine in rats. Neuropharmacology 61: 1399-1405.

D’Souza MS, Liechti ME, Ramirez-Nino AM, Kuczenski R, Markou A. 2011. The metabotropic glutamate $2 / 3$ receptor agonist LY379268 blocked nicotine-induced increases in nucleus accumbens shell dopamine only in the presence of a nicotine-associated context in rats. Neuropsychopharmacology 36: 2111-2124.

Dewey SL, Brodie JD, Gerasimov M, Horan B, Gardner EL, Ashby CR Jr. 1999. A pharmacologic strategy for the treatment of nicotine addiction. Synapse 31: 76-86.

Dravolina OA, Zakharova ES, Shekunova EV, Zvartau EE, Danysz W, Bespalov AY. 2007. mGlu1 receptor blockade attenuates cue- and nicotine-induced reinstatement of extinguished nicotine self-administration behavior in rats. Neuropharmacology 52: 263-269.

Epping-Jordan MP, Watkins SS, Koob GF, Markou A. 1998. Dramatic decreases in brain reward function during nicotine withdrawal. Nature 393: 76-79.

Fadda P, Scherma M, Fresu A, Collu M, Fratta W. 2003. Baclofen antagonizes nicotine-, cocaine-, and morphine-induced dopamine release in the nucleus accumbens of rat. Synapse 50: 1-6.

Fattore L, Spano MS, Cossu G, Scherma M, Fratta W, Fadda P. 2009. Baclofen prevents drug-induced reinstatement of extinguished nicotine-seeking behaviour and nicotine place preference in rodents. Eur Neuropsychopharmacol 19: 487-498.

Fenster CP, Hicks JH, Beckman ML, Covernton PJ, Quick MW, Lester RA. 1999. Desensitization of nicotinic receptors in the central nervous system. Ann NY Acad Sci 868: $620-623$.

Franklin TR, Harper D, Kampman K, Kildea-McCrea S, Jens W, Lynch KG, O’Brien CP, Childress AR. 2009. The GABA B agonist baclofen reduces cigarette consumption 


\section{M.S. D'Souza and A. Markou}

in a preliminary double-blind placebo-controlled smoking reduction study. Drug Alcohol Depend 103: 30-36.

Friedman GD, Siegelaub AB. 1980. Changes after quitting cigarette smoking. Circulation 61: 716-723.

Fu Y, Matta SG, Gao W, Brower VG, Sharp BM. 2000. Systemic nicotine stimulates dopamine release in nucleus accumbens: Re-evaluation of the role of $\mathrm{N}$-methyl-D-aspartate receptors in the ventral tegmental area. J Pharmacol Exp Ther 294: 458-465.

Fudala PJ, Teoh KW, Iwamoto ET. 1985. Pharmacologic characterization of nicotine-induced conditioned place preference. Pharmacol Biochem Behav 22: 237-241.

Gao M, Jin Y, Yang K, Zhang D, Lukas RJ, Wu J. 2010. Mechanisms involved in systemic nicotine-induced glutamatergic synaptic plasticity on dopamine neurons in the ventral tegmental area. J Neurosci 30: 13814-13825.

Geisler S, Trimble M. 2008. The lateral habenula: No longer neglected. CNS Spectr 13: 484-489.

Geisler S, Wise RA. 2008. Functional implications of glutamatergic projections to the ventral tegmental area. $R e v$ Neurosci 19: $227-244$.

Geisler S, Zahm DS. 2005. Afferents of the ventral tegmental area in the rat-anatomical substratum for integrative functions. J Comp Neurol 490: 270-294.

Giovino GA. 2007. The tobacco epidemic in the United States. Am J Prev Med 33: S318-S326.

Grabus SD, Martin BR, Brown SE, Damaj MI. 2006. Nicotine place preference in the mouse: Influences of prior handling, dose and strain and attenuation by nicotinic receptor antagonists. Psychopharmacology (Berl) 184: 456-463.

Guery S, Floersheim P, Kaupmann K, Froestl W. 2007. Syntheses and optimization of new GS39783 analogues as positive allosteric modulators of $\mathrm{GABA}_{\mathrm{B}}$ receptors. Bioorg Med Chem Lett 17: 6206-6211.

Harrison AA, Gasparini F, Markou A. 2002. Nicotine potentiation of brain stimulation reward reversed by $\mathrm{DH} \beta \mathrm{E}$ and SCH 23390, but not by eticlopride, LY 314582 or MPEP in rats. Psychopharmacology (Berl) 160: 56-66.

Henningfield JE, Goldberg SR. 1983. Nicotine as a reinforcer in human subjects and laboratory animals. Pharmacol Biochem Behav 19: 989-992.

Henningfield JE, Miyasato K, Jasinski DR. 1985. Abuse liability and pharmacodynamic characteristics of intravenous and inhaled nicotine. J Pharmacol Exp Ther 234: $1-12$.

Herd N, Borland R, Hyland A. 2009. Predictors of smoking relapse by duration of abstinence: Findings from the International Tobacco Control (ITC) Four Country Survey. Addiction 104: 2088-2099.

Hollmann M, Heinemann S. 1994. Cloned glutamate receptors. Annu Rev Neurosci 17: 31-108.

Huang YH, Bergles DE. 2004. Glutamate transporters bring competition to the synapse. Curr Opin Neurobiol 14: $346-352$.

Hughes JR, Gust SW, Skoog K, Keenan RM, Fenwick JW. 1991. Symptoms of tobacco withdrawal: A replication and extension. Arch Gen Psychiatry 48: 52-59.

Kalivas PW, O’Brien C. 2008. Drug addiction as a pathology of staged neuroplasticity. Neuropsychopharmacology 33: $166-180$.
Kenny PJ, Markou A. 2004. The ups and downs of addiction: Role of metabotropic glutamate receptors. Trends Pharmacol Sci 25: 265-272.

Kenny PJ, Gasparini F, Markou A. 2003. Group II metabotropic and $\alpha$-amino-3-hydroxy-5-methyl-4-isoxazole propionate (AMPA)/kainate glutamate receptors regulate the deficit in brain reward function associated with nicotine withdrawal in rats. J Pharmacol Exp Ther 306: 1068-1076.

Kenny PJ, Chartoff E, Roberto M, Carlezon WA Jr, Markou A. 2009. NMDA receptors regulate nicotine-enhanced brain reward function and intravenous nicotine self-administration: Role of the ventral tegmental area and central nucleus of the amygdala. Neuropsychopharmacology 34: 266-281.

Knackstedt LA, LaRowe S, Mardikian P, Malcolm R, Upadhyaya H, Hedden S, Markou A, Kalivas PW. 2009. The role of cystine-glutamate exchange in nicotine dependence in rats and humans. Biol Psychiatry 65: 841-845.

Koob GF, Volkow ND. 2010. Neurocircuitry of addiction. Neuropsychopharmacology 35 (Erratum): 1051.

Kornetsky C, Esposito RU. 1979. Euphorigenic drugs: Effects on the reward pathways of the brain. Fed Proc 38: 2473-2476.

Kosowski AR, Cebers G, Cebere A, Swanhagen AC, Liljequist S. 2004. Nicotine-induced dopamine release in the nucleus accumbens is inhibited by the novel AMPA antagonist ZK200775 and the NMDA antagonist CGP39551. Psychopharmacology (Berl) 175: 114-123.

Le Foll B, Goldberg SR. 2005a. Control of the reinforcing effects of nicotine by associated environmental stimuli in animals and humans. Trends Pharmacol Sci 26: 287-293.

Le Foll B, Goldberg SR. 2005b. Nicotine induces conditioned place preferences over a large range of doses in rats. Psychopharmacology (Berl) 178: 481-492.

Levin ED, Slade S, Wells C, Petro A, Rose JE. 2011. D-Cycloserine selectively decreases nicotine self-administration in rats with low baseline levels of response. Pharmacol Biochem Behav 98: 210-214.

Liechti ME, Markou A. 2007. Interactive effects of the mGlu5 receptor antagonist MPEP and the mGlu2/3 receptor antagonist LY341495 on nicotine self-administration and reward deficits associated with nicotine withdrawal in rats. Eur J Pharmacol 554: 164-174.

Liechti ME, Lhuillier L, Kaupmann K, Markou A. 2007. Metabotropic glutamate $2 / 3$ receptors in the ventral tegmental area and the nucleus accumbens shell are involved in behaviors relating to nicotine dependence. J Neurosci 27: 9077-9085.

Malin DH, Lake JR, Smith TD, Khambati HN, MeyersPaal RL, Montellano AL, Jennings RE, Erwin DS, Presley SE, Perales BA. 2006. Bupropion attenuates nicotine abstinence syndrome in the rat. Psychopharmacology (Berl) 184: 494-503.

Mansvelder HD, McGehee DS. 2002. Cellular and synaptic mechanisms of nicotine addiction. J Neurobiol 53 606-617.

Mansvelder HD, Keath JR, McGehee DS. 2002. Synaptic mechanisms underlie nicotine-induced excitability of brain reward areas. Neuron 33: 905-919. 
Mao D, Gallagher K, McGehee DS. 2011. Nicotine potentiation of excitatory inputs to ventral tegmental area dopamine neurons. J Neurosci 31: 6710-6720.

Markou A. 2008. Neurobiology of nicotine dependence. Philos Trans R Soc Lond B Biol Sci 363: 3159-3168.

Markou A, Koob GF. 1993. Intracranial self-stimulation thresholds as a measure of reward. In Behavioral neuroscience: A practical approach (ed. Sahgal A) pp. 93-115. IRL Press, Oxford.

Markou A, Weiss F, Gold LH, Caine SB, Schulteis G, Koob GF. 1993. Animal models of drug craving. Psychopharmacology (Berl) 112: 163-182

Martin BR, Aceto MD. 1981. Nicotine binding sites and their localization in the central nervous system. Neurosci Biobehav Rev 5: 473-478.

McBean GJ. 2002. Cerebral cystine uptake: A tale of two transporters. Trends Pharmacol Sci 23: 299-302.

McGeehan AJ, Olive MF. 2003. The mGluR5 antagonist MPEP reduces the conditioned rewarding effects of cocaine but not other drugs of abuse. Synapse 47: 240-242.

Mombereau C, Lhuillier L, Kaupmann K, Cryan JF. 2007. $\mathrm{GABA}_{\mathrm{B}}$ receptor-positive modulation-induced blockade of the rewarding properties of nicotine is associated with a reduction in nucleus accumbens $\Delta$ FosB accumulation. J Pharmacol Exp Ther 321: 172-177.

Palmatier MI, Liu X, Donny EC, Caggiula AR, Sved AF. 2008. Metabotropic glutamate 5 receptor (mGluR5) antagonists decrease nicotine seeking, but do not affect the reinforcement enhancing effects of nicotine. Neuropsychopharmacology 33: 2139-2147.

Papp M, Gruca P, Willner P. 2002. Selective blockade of drug-induced place preference conditioning by ACPC, a functional NDMA-receptor antagonist. Neuropsychopharmacology 27: 727-743.

Paterson NE, Markou A. 2002. Increased GABA neurotransmission via administration of $\gamma$-vinyl GABA decreased nicotine self-administration in the rat. Synapse 44: 252-253.

Paterson NE, Markou A. 2005. The metabotropic glutamate receptor 5 antagonist MPEP decreased break points for nicotine, cocaine and food in rats. Psychopharmacology (Berl) 179: 255-261.

Paterson NE, Semenova S, Gasparini F, Markou A. 2003. The mGluR5 antagonist MPEP decreased nicotine self-administration in rats and mice. Psychopharmacology (Berl) 167: 257-264.

Paterson NE, Froestl W, Markou A. 2004. The $\mathrm{GABA}_{\mathrm{B}}$ receptor agonists baclofen and CGP44532 decreased nicotine self-administration in the rat. Psychopharmacology (Berl) 172: 179-186.

Paterson NE, Froestl W, Markou A. 2005. Repeated administration of the $\mathrm{GABA}_{\mathrm{B}}$ receptor agonist CGP44532 decreased nicotine self-administration, and acute administration decreased cue-induced reinstatement of nicotineseeking in rats. Neuropsychopharmacology 30: 119-128.

Paterson NE, Vlachou S, Guery S, Kaupmann K, Froestl W, Markou A. 2008. Positive modulation of $\mathrm{GABA}_{\mathrm{B}}$ receptors decreased nicotine self-administration and counteracted nicotine-induced enhancement of brain reward function in rats. J Pharmacol Exp Ther 326: 306-314.
Quick MW, Lester RA. 2002. Desensitization of neuronal nicotinic receptors. J Neurobiol 53: 457-478.

Reid MS, Fox L, Ho LB, Berger SP. 2000. Nicotine stimulation of extracellular glutamate levels in the nucleus accumbens: Neuropharmacological characterization. Synapse 35: 129-136.

Risinger FO, Oakes RA. 1995. Nicotine-induced conditioned place preference and conditioned place aversion in mice. Pharmacol Biochem Behav 51: 457-461.

Rutten K, Van Der Kam EL, De Vry J, Bruckmann W, Tzschentke TM. 2011. The mGluR5 antagonist 2-methyl-6-(phenylethynyl)-pyridine (MPEP) potentiates conditioned place preference induced by various addictive and non-addictive drugs in rats. Addict Biol 16: 108-115.

Schilstrom B, Nomikos GG, Nisell M, Hertel P, Svensson TH. 1998. N-methyl-D-aspartate receptor antagonism in the ventral tegmental area diminishes the systemic nicotine-induced dopamine release in the nucleus accumbens. Neuroscience 82: 781-789.

Seguela P, Wadiche J, Dineley-Miller K, Dani JA, Patrick JW. 1993. Molecular cloning, functional properties, and distribution of rat brain $\alpha_{7}$ : A nicotinic cation channel highly permeable to calcium. J Neurosci 13: 596-604.

Shaham Y, Shalev U, Lu L, De Wit H, Stewart J. 2003. The reinstatement model of drug relapse: History, methodology and major findings. Psychopharmacology (Berl) 168: $3-20$.

Shiffman SM, Jarvik ME. 1976. Smoking withdrawal symptoms in two weeks of abstinence. Psychopharmacology (Berl) 50: 35-39.

Shoaib M, Stolerman IP, Kumar RC. 1994. Nicotine-induced place preferences following prior nicotine exposure in rats. Psychopharmacology (Berl) 113: 445-452.

Stack NM. 2007. Smoking cessation: An overview of treatment options with a focus on varenicline. Pharmacotherapy 27: 1550-1557.

Stolerman IP, Jarvis MJ. 1995. The scientific case that nicotine is addictive. Psychopharmacology (Berl) 117: 2-10; discussion 14-20.

Tang AH, Karson MA, Nagode DA, McIntosh JM, Uebele VN, Renger JJ, Klugmann M, Milner TA, Alger BE. 2011. Nerve terminal nicotinic acetylcholine receptors initiate quantal GABA release from perisomatic interneurons by activating axonal T-type $\left(\mathrm{Ca}_{\mathrm{v}} 3\right) \mathrm{Ca}^{2+}$ channels and $\mathrm{Ca}^{2+}$ release from stores. J Neurosci 31: 13546-13561.

Tronci V, Balfour DJ. 2011. The effects of the mGluR5 receptor antagonist 6-methyl-2-(phenylethynyl)-pyridine (MPEP) on the stimulation of dopamine release evoked by nicotine in the rat brain. Behav Brain Res 219: $354-357$.

Tronci V, Vronskaya S, Montgomery N, Mura D, Balfour DJ. 2010. The effects of the mGluR5 receptor antagonist 6-methyl-2-(phenylethynyl)-pyridine (MPEP) on behavioural responses to nicotine. Psychopharmacology (Berl) 211: 33-42.

Vlachou S, Guery S, Froestl W, Banerjee D, Benedict J, Finn MG, Markou A. 2011a. Repeated administration of the $\mathrm{GABA}_{\mathrm{B}}$ receptor positive modulator BHF177 decreased nicotine self-administration, and acute administration decreased cue-induced reinstatement of nicotine seeking in rats. Psychopharmacology (Berl) 215: 117-128. 


\section{M.S. D'Souza and A. Markou}

Vlachou S, Paterson NE, Guery S, Kaupmann K, Froestl W, Banerjee D, Finn MG, Markou A. 2011b. Both $\mathrm{GABA}_{B}$ receptor activation and blockade exacerbated anhedonic aspects of nicotine withdrawal in rats. Eur J Pharmacol 655: $52-58$.

Wang F, Chen H, Steketee JD, Sharp BM. 2007. Upregulation of ionotropic glutamate receptor subunits within specific mesocorticolimbic regions during chronic nicotine self-administration. Neuropsychopharmacology 32: $103-109$.

Wang LP, Li F, Shen X, Tsien JZ. 2010. Conditional knockout of NMDA receptors in dopamine neurons prevents nicotine-conditioned place preference. PLOS ONE 5: e8616.

Watkins SS, Epping-Jordan MP, Koob GF, Markou A. 1999. Blockade of nicotine self-administration with nicotinic antagonists in rats. Pharmacol Biochem Behav 62: 743751.
Watkins SS, Koob GF, Markou A. 2000. Neural mechanisms underlying nicotine addiction: Acute positive reinforcement and withdrawal. Nicotine Tob Res 2: 19-37.

Wise RA. 1987. The role of reward pathways in the development of drug dependence. Pharmacol Ther 35: 227-263.

Wonnacott S. 1997. Presynaptic nicotinic ACh receptors. Trends Neurosci 20: 92-98.

World Health Organization. 2008. WHO Report on the Global Tobacco Epidemic. World Health Organization, Geneva.

Yang K, Buhlman L, Khan GM, Nichols RA, Jin G, McIntosh JM, Whiteaker P, Lukas RJ, Wu J.2011. Functional nicotinic acetylcholine receptors containing $\alpha 6$ subunits are on GABAergic neuronal boutons adherent to ventral tegmental area dopamine neurons. J Neurosci 31: 2537-2548.

Yararbas G, Keser A, Kanit L, Pogun S. 2010. Nicotine-induced conditioned place preference in rats: Sex differences and the role of mGluR5 receptors. Neuropharmacology 58: $374-382$. 


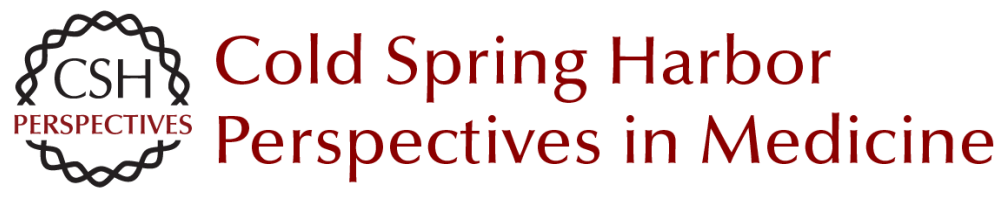

\title{
The "Stop" and "Go" of Nicotine Dependence: Role of GABA and Glutamate
}

\author{
Manoranjan S. D'Souza and Athina Markou \\ Cold Spring Harb Perspect Med 2013; doi: 10.1101/cshperspect.a012146
}

\section{Subject Collection Addiction}

Developments from Bulk Optogenetics to

Single-Cell Strategies to Dissect the Neural

Circuits that Underlie Aberrant Motivational States

Jose Rodriguez-Romaguera, Vijay M.K.

Namboodiri, Marcus L. Basiri, et al.

Consequences of Parental Opioid Exposure on

Neurophysiology, Behavior, and Health in the

Next Generations

Fair M. Vassoler and Mathieu E. Wimmer

Animal Models of the Behavioral Symptoms of

Substance Use Disorders Louk J.M.J. Vanderschuren and Serge H. Ahmed

Translational Research in Nicotine Addiction Miranda L. Fisher, James R. Pauly, Brett Froeliger, et al.

Neonatal Opioid Withdrawal Syndrome (NOWS): A Transgenerational Echo of the Opioid Crisis Andrew E. Weller, Richard C. Crist, Benjamin C. Reiner, et al.

Impairment of Synaptic Plasticity by Cannabis, $\Delta^{\mathbf{9}}$ -THC, and Synthetic Cannabinoids

Alexander F. Hoffman, Eun-Kyung Hwang and Carl R. Lupica

Drug-Evoked Synaptic Plasticity of Excitatory

Transmission in the Ventral Tegmental Area Camilla Bellone, Michael Loureiro and Christian Lüscher

Opioid-Induced Molecular and Cellular Plasticity

of Ventral Tegmental Area Dopamine Neurons

Marie A. Doyle and Michelle S. Mazei-Robison
The Persistent Challenge of Developing Addiction

Pharmacotherapies

Sarah E. Swinford-Jackson, Charles P. O'Brien,

Paul J. Kenny, et al.

Opioid Modulation of the Gut-Brain Axis in Opioid-Associated Comorbidities

Li Zhang and Sabita Roy

Epigenetics of Drug Addiction

Andrew F. Stewart, Sasha L. Fulton and lan Maze

Genetic Vulnerability to Opioid Addiction

Brian Reed and Mary Jeanne Kreek

Glutamatergic Systems and Memory Mechanisms Underlying Opioid Addiction

Jasper A. Heinsbroek, Taco J. De Vries and Jamie Peters

Mechanisms of Nicotine Addiction

Marina R. Picciotto and Paul J. Kenny

Neural Substrates and Circuits of Drug Addiction Matthew W. Feltenstein, Ronald E. See and Rita A. Fuchs

The Role of the Central Amygdala in Alcohol

Dependence Marisa Roberto, Dean Kirson and Sophia Khom

For additional articles in this collection, see http://perspectivesinmedicine.cshlp.org/cgi/collection/ 